\title{
SUPERVIVENCIA Y TRANSCENDENCIA \\ DE INMIGRANTES LATINAS INDÍGENAS TRANSNACIONALES (ILIS) \\ EN LOS ESTADOS UNIDOS
}

\author{
SURVIVAL AND TRANSCENDENCE \\ OF TRANSNATIONAL INDIGENOUS LATINA IMMIGRANTS (ILIS) IN THE US
}

\section{SOBREVIVÊNCIA E TRANSCENDÊNCIA}

TRANSNACIONAL IMIGRANTES LATINA INDIFENOUS (ILIS) NOS EUA

\author{
Margarita Machado-Casas \\ Universidad de Texas en SAN ANTONIO, Estadoos Unidos
}

\begin{abstract}
RESUMEN: Los inmigrantes latinos indígenas transnacionales parecen vivir hoy vidas múltiples a través de múltiples fronteras. Basado en un estudio de investigación de métodos mixtos llevado a cabo en 3 años y que tuvo lugar en Carolina del norte, este manuscrito describe las experiencias de inmigrantes latinas indígenas (ILIs) que viven en los Estados Unidos, específicamente las pedagogías de supervivencia basadas en identidades sociales fluidas. Las mujeres indígenas que participaron en este estudio tuvieron que adoptar identidades fluidas desconocidas tanto en el hogar para lograr la supervivencia cultural como fuera del hogar (identidades externas) para la supervivencia física y social, a menudo en ambientes hostiles. Además, plantea preguntas acerca de las maneras en que el multilingüismo afecta la movilidad por las fronteras y la trans-nacionalidad, así como la conversión de las inmigrantes latinas indígenas en Camaleónas guerreras (camaleón guerreros) que utilizan "herramientas de supervivencia crítica" como un puente transnacional para facilitar su supervivencia en ambientes hostil de los Estados Unidos, la comunidad y en las escuelas.
\end{abstract}

PALABRAS CLAVE: Transnacional; Indígenas; Inmigrante Latina; Supervivencia; Inmigración; Educación.

ABSTRACT: Transnational indigenous Latino immigrants today seem to live multiple lives across multiple borders. Based on a 3-year Mix methods research study that took place in North Carolina, the manuscript describes the experiences of Indigenous Latina Immigrants (ILIs) living in the United States, specifically pedagogies of survival based on fluid social identities. The indigenous women who took part in this study had to adopt fluid unknown identities both at home for cultural survival, and also outside home (external iden- 
tities) for physical and social survival, often in hostile environments. In addition, it raises questions about how multilingualism affects border mobility and transnationality as well as how indigenous Latina immigrants become Camaleónas guerreras (Chameleon Warriors) who use "critical survival tools" as a transnational bridge to facilitate their survival in a hostile US environment, the community, and at schools.

KEYWORDS: Transnational; Indigenous; Latina Immigrant; Survival; Immigration; Education.

RESUMO: Transnacionais imigrantes latinos indígenas hoje parecem viver várias vidas em várias fronteiras. Com base em um estudo de pesquisa métodos Mix de 3 anos que teve lugar na Carolina do Norte, o manuscrito descreve as experiências de imigrantes Latina Indígenas (llis) que vivem nos Estados Unidos, especificamente pedagogias de sobrevivência com base em identidades sociais fluidas. As mulheres indígenas que participaram neste estudo tiveram que adotar fluidas identidades desconhecidas, tanto em casa para a sobrevivência cultural, e também fora de casa (identidades externas) para a sobrevivência física e social, muitas vezes em ambientes hostis. Além disso, levanta questões sobre como o multilinguismo afeta mobilidade e transnacionalidade fronteira, bem como a forma como indígena Latina imigrantes se Camaleonas guerreras (guerreiros Chameleon) que usam "ferramentas essenciais de sobrevivência", como uma ponte transnacional para facilitar a sua sobrevivência em um ambiente hostil dos EUA, o comunidade e nas escolas.

PALAVRAS-CHAVE: Transnacional; Indígena; Latina Imigrante; Survival; Imigração; Educação. 
En este país, somos camaleones y guerreras.

Hemos aprendido que tenemos que adaptarnos para poder sobrevivir, pero lo más importante es que somos el foco de lo que será el futuro de nuestros hijos. Es nuestro deber asegurarnos de que sepan cómo ser camaleones, también.

Maricela

\section{Introducción}

Los comentarios anteriores de Maricela contrarrestan los estereotipos asociados a muchas mujeres indigenas latinas inmigrantes (ILI) y los inmigrantes latinos en los Estados Unidos de ser "pasivos, inactivos e indiferente con respecto a la educación" (Delgado-Gaitán, 1990, pág. 1). Y, sus comentarios destacan la complejidad de las identidades lingüisticas, experiencias y vidas de las mujeres y como las mujeres ILI trabajan y luchan para ayudar a sus hijos a lograr las identidades lingüísticas transnacionales. Las mujeres indígenas que participaron en este estudio tuvieron que adoptar identidades fluidas y características desconocidas para adaptarse a situaciones especificas. Estas identidades se promulgaron tanto en el hogar para lograr la supervivencia cultural y también fuera del hogar (identidades externas) para la supervivencia física y social, a menudo en ambientes hostiles. Las identidades fluidas promulgadas por ILIs facilitan su transnacionalidad, o su capacidad de pertenecer y sobrevivir en dos o más espacios sociales (MachadoCasas, 2006; Sánchez, 2007; Trueba, 2004) al “ayudarles a cruzar las fronteras virtualmente, fortaleciendo los lazos políticos, sociales y financieros con sus comunidades de origen y a la vez permanecer invisibles a sus opresores, que pueden o no ser de sus comunidades de origen" (MachadoCasas, 2009). Para las mujeres ILI participantes en este estudio, esta responsabilidad les corresponde principalmente a ellas como guardianes, pero más importante como camaleónas guerreras (guerreros camaleón) que tuvieron que adoptar múltiples identidades extranjeras en diferentes, pero a la vez" críticos entornos" en los Estados Unidos.

Al aplicar el concepto de transnacionalidad y movilidad social a las realidades de las mujeres latinas indígenas multilingües en los Estados Unidos, este artículo explora las siguientes preguntas: (a) ¿Cua-
In this country, we are chameleons and warriors. We learned that we have to adapt in order to survive, but most importantly that we are the center of what will be the future of our children. It is our duty to make sure they know how to be chameleons, too. Maricela

\section{Introduction}

Maricela's comments above counter the stereotypes associated with many Indigenous Latino Immigrant (ILI) women and Latino immigrants in the US of being "passive, inactive, and uncaring about education" (Delgado-Gaitan, 1990, pg. 1). And, her comments highlight the complexities of women's linguistic identities, experiences, and lives as ILI women work and fight to help their children achieve transnational linguistic identities. The indigenous women who took part in this study had to adopt fluid unknown identities and characteristics in order to adapt to specific situations. These identities were enacted both in the home for cultural survival, and also outside the home (external identities) for physical and social survival, often in hostile environments. The fluid identities enacted by ILIs facilitated their transnationality, or their ability to be part of and survive in more than two social spaces (Machado-Casas, 2006; Sanchez, 2007; Trueba, 2004) by "helping them cross borders virtually, strengthening political, social and financial ties to their communities of origin while remaining invisible to their oppressors, who may or may not be from the communities of origin" (Machado-Casas, 2009). For the ILI women in this study, this responsibility was left mostly to them as caregivers, but most importantly as camaleónas guerreras (chameleon warriors) who had to enact multiple foreign identities in different, yet "critical survival settings" in the United States.

In applying the concept of transnationality and social mobility to the realities of multilingual Latino indigenous women in the US, this article explores following questions: (a) What are "critical survival settings" or spaces for ILI women, both internal and external? (b) What is the role of multilingualism, and how does this ability affect border mobility, accessibility, and transnationality for Latina indigenous women in this study? (c) How do ILI women pass on 
les son los "escenarios de supervivencia crítica" o espacios para las mujeres ILI, tanto internas como externas? (b) ¿Cuál es el papel del multilingüismo, y cómo esta habilidad afecta la movilidad fronteriza, la accesibilidad y la transnacionalidad para las mujeres Latinas indígenas en este estudio? (c) ¿De qué manera las mujeres ILI transmiten los caudales de conocimientos "transnacional" a sus hijos como una forma de prepararlos para afrontar la vida como pueblos indígenas multilingües en los Estados Unidos?

\section{Mujeres Multilingüe y Multicultural ILI, Fami- lias y Comunidades en los Estados Unidos}

Las investigaciones demuestran que la población inmigrante Latina en los Estados Unidos se compone predominantemente por pueblos indígenas provenientes de las zonas rurales (Flores, Henández-León \& Massey, 2004; Machado-Casas, 2009). "La incorporación de un gran número de pueblos indígenas en el flujo migratorio mexicano hacia Estados Unidos ilustra cómo están cambiando dramáticamente los patrones de migración" (Rivera-Salgado, 1999, p. 1440). Dado los patrones migratorios que incluyen más personas de las zonas rurales, muchas comunidades de inmigrantes son multiculturales, multilingües y no dependientes exclusivamente del español. Sin embargo, todavía en los Estados Unidos cuando se piensa en los inmigrantes latinos, uno piensa en personas de habla hispana provenientes de ciudades urbanas en América Latina, o en el caso de México y Guatemala, de las áreas rurales remotas.

Otros investigadores que han estudiado los movimientos migratorios reportan que las comunidades mixtecas, Nahuas, Purepechas, Triques y Otomí se encuentran entre los mayores grupos indígenas que emigran a Estados Unidos (Anderson, 1997; Stephen, 2007; Zabin, Kearny, Garcia, Runsten \& Nagengast, 1993). En años anteriores, los pueblos indígenas mexicanos tendían a migrar a las grandes ciudades en áreas tales como California y Texas que tienen una larga historia de migración Mexicana (Fox \& Salgado, 2004). Esa tendencia ha cambiado; los inmigrantes recién llegados, incluyendo los inmigrantes indígenas, actualmente están entrando en Estados que históricamente no han tenido grandes poblaciones de inmigrantes latinos, tales como Carolina del Norte (Machado-Casas, 2006; Grupo \& Suro, 2005). Los "transnational" funds of knowledge to their children as a way of preparing them for life as multilingual indigenous peoples in the United States?

\section{ILI Multilingual-Multicultural Women, Fami- lies and Communities in the United States}

Research shows that the Latino immigrant population in the United States is predominantly comprised of indigenous people from rural areas (Flores, Henández-León, \& Massey, 2004; Machado-Casas, 2009). "The incorporation of large numbers of indigenous peoples in the US-bound Mexican migratory flow illustrates just how dramatically migration patterns are changing" (Rivera-Salgado, 1999, p. 1440). With migratory patterns including more people from rural areas, many immigrant communities are multicultural, multilingual, and not bound solely by Spanish. Yet, still in the US when one thinks of Latino immigrants in the United States, one thinks of Spanish-speaking people from urban cities in Latin America, or in the case of Mexico and Guatemala, remote rural areas.

Other researchers who have studied migration shifts report that Mixtec, Nahuas, Purepechas, Triques, and Otomí communities are among the largest indigenous groups migrating to the United States (Anderson, 1997; Stephen, 2007; Zabin, Kearny, Garcia, Runsten, \& Nagengast, 1993). In years past, Mexican indigenous peoples tended to migrate to large cities in areas such as California and Texas with long-standing histories of migration from Mexico (Fox \& Salgado, 2004). That trend has shifted; newly-arrived immigrants, including indigenous immigrants, are currently entering states that historically have not had large Latino immigrant populations, such as North Carolina (Machado-Casas, 2006; Passel \& Suro, 2005). ILIs have unique sociocultural practices and identities that are not bound solely to language, with important implications for schools and communities in the United States.

[ 24 ] MARGARITA MACHADO-CASAS

SIPS - PEDAGOGIA SOCIAL. REVISTA INTERUNIVERSITARIA [1139-1723 (2014) 23, 21-44] TERCERA ÉPOCA 
ILls tienen prácticas socioculturales e identidades particulares que no están limitadas únicamente a la lengua y conllevan importantes implicaciones para las escuelas y comunidades en los Estados Unidos.

\section{Las mujeres, indígenas, pero también inmigrantes en los Estados Unidos}

Para muchos inmigrantes indígenas, la identidad no está necesariamente vinculada a un estado-nación, sino más bien a una comunidad indígena o a un grupo en su país de origen (Machado-Casas, 2010). Conceptualizando las experiencias ILI en los Estados Unidos, Machado-Casas (2009) se refiere al término oculto, que significa escondido o ignorado. En los Estados Unidos, el término de comunidad indígena a menudo se refiere a un grupo de nativos americanos; en contraste, los inmigrantes que son miembros de tribus indígenas permanecen ocultos. Esto es particularmente cierto para las mujeres indígenas que a menudo no son registradas o son ignoradas en el censo. Según un informe del Buró de Censo de Estados Unidos escrito por Gibson y Lennon (1999), hasta los años sesenta, había mayor número de hombres inmigrantes que mujeres, "para los años 70 el número de mujeres inmigrantes alcanzó al número de hombres y los superó. En el año 2010 por cada 100 mujeres inmigrantes llegaban 96 hombres"(p. 1). En 2008, había 18,9 millones de mujeres inmigrantes en Estados Unidos representando el 49.9 por ciento del total de la población inmigrante. Contabilizando más de una cuarta parte de todas las personas nacidas en el extranjero; las mujeres de México son el grupo más grande de mujeres inmigrantes en los Estados Unidos (Immigration Policy Center, 2010). Aunque se hacen distinciones en términos de género en muchos informes sobre los inmigrantes en Estados Unidos, no existe una categoría para las mujeres que son de ascendencia indígena, un grupo de rápido crecimiento.

El no reconocer esta diversidad demográfica tiene varias implicaciones. En primer lugar, las amplias y categóricas suposiciones acerca de los Latinos no reflejan necesariamente a las mujeres inmigrantes indígenas de América Latina, especialmente en términos de lenguaje y prácticas culturales. En segundo lugar, las mujeres que participaron en este estudio eran indocumentadas, lo que au-

\section{Women, Indigenous, but also Immigrants in the United States}

For many indigenous immigrants, identity is not necessarily tied to a nation-state, but instead to an indigenous community or group in their country of origin (Machado-Casas, 2010). Conceptualizing ILI experiences in the United States, Machado-Casas (2009) referred to the term oculto, meaning hidden, unseen or ignored. In the United States, the term indigenous community most often refers to a group of Native Americans; in contrast, immigrants who are members of indigenous tribes remain ocultos. This is particularly true for indigenous women who often are not counted or are ignored in the census. According to a US Census Bureau report written by Gibson and Lennon (1999), until the 1960s, immigrant men outnumbered immigrant women, "by the 1970s the number of female immigrants caught up and surpassed their male counterparts. In 2010 there were 96 immigrant men arriving for every 100 immigrant women" (p. 1). In 2008, there were 18.9 million female immigrants in the United States, 49.9 percent of the total immigrant population. Accounting for more than one-quarter of all foreign-born people, females from Mexico are the single largest group of female immigrants in the United States (Immigration Policy Center, 2010). Although distinctions are made in terms of gender in many reports on immigrants in the United States, no category exists for women who are of indigenous descent, a rapidly growing group.

Failing to recognize this demographic diversity has several implications. First, broad categorical assumptions about Latinos do not necessarily apply to indigenous immigrant women from Latin America, especially in terms of language and cultural practices. Second, the women who participated in this study were undocumented, which heightened their risk of detention or deportation and losing contact with their American-born children. Their status causes them to remain in the shadows, their voices silent. Because their identities often remain ocultas, myths and stereotypes proliferate, creating obstacles for 
menta su riesgo de detención o deportación y a perder el contacto con sus hijos nacidos en Estados Unidos. Su condición de indocumentadas las obliga a permanecer en las sombras, con sus voces silenciadas; porque sus identidades a menudo permanecen ocultas, proliferan los mitos y estereotipos, creando obstáculos difíciles de superar para las mujeres inmigrantes en Estados Unidos.

\section{Diversidad sociolingüística de ILls en los Estados Unidos}

En los Estados Unidos a menudo se asume que el español es la lengua materna de todos los inmigrantes latinos, esto es una suposición que abraza la identidad étnica Español (Gallego, 1998) y tiende a "ignorar (ocultar) las complejidades y ámbitos de los tipos de clase, política étnica, género y el sometimiento de las poblaciones indígenas que se vieron obligadas por los colonizadores a mezclar" (Machado-Casas, 2009, p. 6). Refiriéndose a las poblaciones indígenas mexicanas, Fox (2006) señaló que estos términos se utilizan indistintamente como "identidades colectivas que complican ampliamente las ideas sobre raza, etnicidad e identidad nacional" y que "en los Estados Unidos, raza, origen étnico y la identidad nacional no son sinónimos" (p. 40). De hecho, miembros de las comunidades indígenas no son mencionadas en los discursos sobre los inmigrantes Latino /a en los Estados Unidos a como es "el uso de un término pan-étnico tal como Latino para incluir a todos los de ascendencia latinoamericana sin distinguir las diferencias regionales; sirve sólo como otra forma de opresión continuada, marginalización y la colonización de las comunidades indígenas; uno debe tener cuidado al generalizar las características de quienes son considerados Latinos y sus implicaciones en la vida de las personas"(Machado-Casas, 2009, p. 6). El no considerar las diferencias socioculturales y lingüísticas entre los inmigrantes en los Estados Unidos margina importantes distinciones regionales entre diferentes grupos de inmigrantes siguiendo así con una cultura de colonización y perpetúa los estereotipos asociados a una "identidad colectiva" (Fox, 2006).

Esta situación es aún más conmovedora al examinar las experiencias educativas de los ILIs en los Estados Unidos ya que muchos educadores asumen immigrant women in the United States that are difficult to overcome.

\section{Sociolinguistic Diversity of ILIs in the United States}

In the United States it is often assumed that Spanish is the native tongue for all Latino immigrants, this is an assumption that embraces the Spanish ethnic identity (Gallego, 1998) and tends to "ignore (ocultar) the complexities and localities of class types, ethnic politics, gender and the subjugation of indigenous populations who were forced to mix by colonizers" (Machado-Casas, 2009, p. 6). Referring to Mexican indigenous populations, Fox (2006) pointed out that these terms are used interchangeably as "collective identities that widely complicate held ideas about race, ethnicity, and national identity" and that "in the US, race, ethnicity, and national identity are not synonyms" (p. 40). Indeed, members of indigenous communities are not mentioned in discourses on Latino/a immigrants in the United States as "the use of a pan-ethnic term such as Latino to include all of Latin American descent without looking at regional differences serves only as another form of continued oppression, marginalization, and colonization of indigenous communities; one needs to be careful when generalizing the characteristics of those who are considered Latinos and its implications on people's lives" (Machado-Casas, 2009, p. 6). Failing to consider socio-cultural and linguistic differences among immigrants in the United States marginalizes important regional distinctions among different immigrant groups by continuing a culture of colonization and perpetuating stereotypes associated with a "collective identity" (Fox, 2006).

These issues become even more poignant when examining ILIs educational experiences the United States as many educators assume that most immigrant families and students are monolingual and monocultural, with similar social practices and experiences. In fact, many educators working with

[ 26 ] MARGARITA MACHADO-CASAS 
que la mayoría de las familias inmigrantes y los estudiantes son monolingües y mono-culturales con experiencias y prácticas sociales similares. De hecho, muchos educadores que trabajan con niños indígenas multilingües latinos ven el uso de otros idiomas como un impedimento para su progreso (Machado-Casas, 2009). Por lo tanto, los ILIs no solo experimentan discriminación que proviene de ser parte de una población de inmigrantes más amplia, pero también reacciones xenófobas dentro de la propia población.

\section{Disertación: Inmigrantes Latinos Indígenas Transnacionales}

Las recientes conceptualizaciones de transnacionalidad generalmente han negado los rápidos cambios demográficos en los Estados Unidos, incluyendo el aumento de la migración de poblaciones rurales e indígenas. Fox (2006) señala, "más de uno en diez mexicanos proviene de una familia en la que se habla una lengua indígena" (p. 39). En consecuencia, los investigadores (Beserrer, 2002, 2004; MachadoCasas, 2009, 2010; Rivera-Salgado, 1999; Stephen, 2007) han reconocido la importancia de incluir a los ILIs al explorar la transnacionalidad y sus definiciones. Este estudio amplía varias disertaciones sobre la transnacionalidad para poder incluir la creciente población ILIs en los Estados Unidos.

Históricamente, el transnacionalismo se ha utilizado en un contexto financiero, refiriéndose a los mercados de mano de obra migrante y las prácticas corporativas de movilizar los trabajadores de un país a otro (Vertovec, 1999). Hoy, sin embargo, diversas conceptualizaciones del término amplían su aplicación más allá de los mercados laborales mediante la inclusión de la movilidad social, la migración, la identidad y la comunidad. Ong (1997) refiriere al transnacionalismo como "las especificidades culturales de los procesos globales" (p. 4) que consta de una tradición cultural que trascienden las fronteras. Los antropólogos definen la transnacionalidad como formaciones sociales que abarcan las fronteras y las diásporas étnicas que sobrepasan a los sitios de entrada y salida (Vertovec, 1999). Basch, Glick Schiller y Blanc-Szanton (1992) conceptualizan la transnacionalidad como migrantes conscientemente identificados más con una identidad étnica que otro (por ejemplo, algunos ILls prefieren pensar de sí mismos indigenous multilingual Latino children see the use of other languages as an impediment to advancement (Machado-Casas, 2009). Thus, ILIs experience discrimination that stems not only from being part of a broader immigrant population, but also xenophobic reactions within the population itself.

\section{Discourse in the Making: Transnational Indigenous Latino Immigrants}

Recent conceptualizations of transnationality have generally neglected rapidly changing demographics in the United States, including increased migration from rural and indigenous populations. Fox (2006) noted, "more than one in ten Mexicans comes from a family in which an indigenous language is spoken" (p. 39). Accordingly, researchers (Beserrer, 2002, 2004; Machado-Casas, 2009, 2010; Rivera-Salgado, 1999; Stephen, 2007) have recognized the importance of including ILIs when exploring transnationality and its definitions. This study expands various discourses on transnationality in order to include the growing number of ILIs in the United States.

Historically, transnationalism has been used in a financial context, referring to migrant labor markets and corporate practices of moving workers from one country to another (Vertovec, 1999). Today, however, various conceptualizations of the term expand its application beyond labor markets by accounting for social mobility, migration, identity, and community transformation. Ong (1997) referred to transnationalism as "cultural specificities of global processes" (p. 4) consisting of cultural traditions that transcend borders. Anthropologists define transnationality as social formations that span borders and ethnic diasporas that surpass sites of entrance and exit (Vertovec, 1999). Glick Schiller, Basch and Szanton-Blanc (1992) conceptualized transnationality as migrants consciously identifying more with one ethnic identity than another (e.g., some ILIs prefer to think of themselves as indigenous over Latino, despite it being necessary to acknowledge both). 
como indígenas en vez de Latino, a pesar de ser necesario reconocer ambos).

Según Trueba (2004) una persona transnacional tiene "una capacidad única de manejar las diferentes culturas y estilos de vida, los diferentes estatus sociales, diferentes roles y relaciones y para funcionar eficazmente en diferentes sistemas sociales, políticos y económicos" (Trueba, 2004, p. 39). Otros investigadores han ampliado esta definición para incluir las poblaciones no fronterizas que no tienen contacto frecuente con sus países de origen. La principal diferencia entre un inmigrante y una persona transnacional es que el inmigrante no tiene contacto frecuente e intensivo con su cultura original y en consecuencia puede eventualmente integrarse en la sociedad y perder su idioma y cultura. (Trueba, 2004, p. 1). Las vidas de los inmigrantes transnacionales y sus familias en los Estados Unidos están en un constante estado de incertidumbre y permanecer conectados a sus países de origen no es un lujo, sino una necesidad independientemente de su proximidad a la frontera. Del mismo modo, Levitt (2001) realizó un estudio con inmigrantes de la República Dominicana que demostró que la migración real no es necesaria para ser miembro de un campo social transnacional. Varios estudios encontraron que incluso sin acceso físico a sus ciudades natales, muchos inmigrantes interactúan a través de las fronteras y mantienen vínculos con la cultura y la lengua, haciéndolos efectivamente transnacionales (Aranda, 2006; Bauch et al., 1992; Levitt, 2001). Estas cuestiones son particularmente relevantes para los recién Ilegados ILIs quienes están aprendiendo a vivir y sobrevivir al otro lado de las fronteras.

El Idioma también desempeña un papel crítico en el discurso y la vida de las transnacionales. Trueba (2004) amplia afirmando que para mantener vínculos transnacionales es importante mantener la lengua materna y el conocimientos del inglés. Otros investigadores están de acuerdo en que el lenguaje es importante, pero principalmente porque promueve la cultura y la validación de la identidad además de proporcionar una manera de mantenerse conectados con familias en los Estados Unidos y en su lugar de origen (Beserrer, 2002, 2004; MachadoCasas, 2006; Stephen, 2007). Además de beneficios asociados con el acceso a diferentes espacios sociales, los transnacionales tienen la necesidad de
According to Trueba (2004) a transnational person has "a unique capacity to handle different cultures and lifestyles, different social statuses, different roles and relationships, and to function effectively in different social, political, and economic systems" (Trueba, 2004, p. 39). Other researchers have expanded this definition to include non-border populations who do not have frequent contact with their countries of origin. The primary difference between an immigrant and a transnational person is that the immigrant does not have frequent and intensive contact with his original culture and consequently can eventually assimilate into mainstream society and lose his home language and culture. (Trueba, 2004, p. 1). The lives of transnational immigrants and their families in the United States are in a constant state of uncertainty and staying connected to their countries of origin is not a luxury, but a necessity regardless of their proximity to the border. Similarly, Levitt (2001) conducted a study with immigrants from the Dominican Republic which showed that actual migration is not required for membership in a transnational social field. Several studies found that even without physical access to their hometowns, many immigrants interact across borders and maintain ties to culture and language, effectively making them transnationals (Aranda, 2006; Bauch et al., 1992; Levitt, 2001). These issues are particularly relevant to newly-arrived ILIs learning to live and survive across borders.

Language also plays a critical role in the discourse and lives of transnationals. Trueba (2004) expanded by stating that in order to maintain transnational ties, native language maintenance and English skills are both important. Other researchers agree that language is important, but mainly because it promotes cultural and identity validation in addition to providing a way to maintain connected with families in the United States and back home (Beserrer, 2002, 2004; MachadoCasas, 2006; Stephen, 2007). In addition to benefits associated with access to different social spaces, transnationals have the need to retain the values, beliefs, and characteristics of more than one culture (Sánchez, 2009), assimilating the best aspects of different worlds. 
conservar los valores, creencias y características de más de una cultura (Sánchez, 2009), asimilando los mejores aspectos de mundos diferentes.

\section{Metodologia}

Este artículo utiliza los datos de un estudio de investigación más amplio con $(n=230)$ participantes sobre la migración, la movilidad y la supervivencia de Latina/os e ILIs dentro de la nueva diáspora Latina en los Estados Unidos (Machado-Casas, 2006). Ya que este estudio se centra en familias ILI (grupos subordinados ausente o tergiversados en relatos históricos), se utilizaron métodos de investigación narrativa (Merriam, 1998) en conjunto con múltiple interactivo (Creswell, 1998) y una mezcla de enfoque de métodos para la recolección de datos a través de múltiples escenarios. Se utilizaron entrevistas abiertas para comprender las experiencias de los participantes. La investigación narrativa (Clandinin \& Conelly, 2002) es especialmente apropiada para este tipo de estudio porque a menudo, las comunidades ILI no están representadas en la escritura; en cambio, tienen una larga historia de comunicación oral. Este estudio también se basa en investigaciones relacionadas con los migrantes indígenas mexicanos (Fox, 2006), inmigrantes de segunda generación (Portes \& Rumbaut, 2001), las diferencias entre las familias multiculturales y las escuelas (Valdés, 1996), la migración de mexicanos (Durand \& Massey, 2004) y la transnacionalidad de inmigrantes latinos (Trueba, 2004). Se celebraron reuniones mensuales con padres de inmigrantes latinos en seis escuelas urbanas en Carolina del Norte durante un período de 3 años. Una encuesta demográfica cuantitativa fue entregada a todos $(n=230)$ los participantes del estudio a su llegada al programa.

Los participantes fueron entrevistados en español en lugares "seguros" elegidos por los participantes para asegurar su privacidad. Las entrevistas tuvieron una duración de aproximadamente 2 a 3 horas y fueron grabadas, transcritas y analizadas. Algunos participantes indígenas tenían traductores ocultos (hidden translators) quienes les ayudaban cuando experimentaban dificultades expresando una palabra o pensamiento en español. Siguiendo lo sugerido por Gándara (1995), a los participantes se les pidió contar sus historias de vida, incluyendo

\section{Methodology}

This paper uses data from a larger research study with $(n=230)$ participants on the migration, mobility, and survival of Latina/os and ILIs within the New Latino Diaspora in the United States (Machado-Casas, 2006). Because this study focuses on ILI families (subordinated groups either absent from or misrepresented in historical accounts), narrative research methods (Merriam, 1998) were coupled with multiple interactive (Creswell, 1998) and mix methods approach were used for data collection across multiple settings. Open-ended interviews were used to understand participant experiences. Narrative research (Clandinin \& Conelly, 2002) is especially appropriate for this type of study because often, ILI communities are not represented in writing; instead, they have a long history of oral communication. This study also builds on research related to Mexican indigenous migrants (Fox, 2006), second-generation immigrants (Portes \& Rumbaut, 2001), differences between culturally diverse families and schools (Valdés, 1996), Mexican migration (Durand \& Massey, 2004) and Latino immigrant transnationality (Trueba, 2004). Monthly meetings with Latino immigrant parents were held at six urban schools in North Carolina over a period of 3 years. A quantitative demographic survey was given to all $(n=230)$ study participants upon their arrival in the program.

Participants were interviewed in Spanish at "safe" locations chosen by the participants to ensure their privacy. Interviews lasted approximately 2 to 3 hours and were recorded, transcribed, and analyzed. Some indigenous participants had traductores ocultos (hidden translators) who assisted them when they experienced difficulties expressing a word or thought in Spanish. As suggested by Gándara (1995), participants were asked to tell their life stories, including life experiences and educational histories in their countries of origin, their migrations to the United States, experiences with the American educational system, and how living in the United States has impacted their cultural, linguistic, and social identities. 
el historial educativo y experiencias de la vida en sus países de origen, sus migraciones a Estados Unidos, las experiencias con el sistema educativo americano, y cómo la vida en los Estados Unidos ha impactado su identidad cultural, lingüístico y social.

\section{El resultado de los datos demográficos}

La encuesta demográfica reveló países de origen de los participantes, la lengua hablada y la nacionalidad. Los participantes habían estado viviendo en los Estados Unidos un promedio de 10,88 años (SD = 8,20) y provenían de una amplia variedad de países de origen, incluyendo Honduras $(n=15)$, El Salvador $(n=40)$, Guatemala $(n=50)$, México $(n=120)$ y otros países de América Central y América del sur $(n=5)$. Entre 20 y 30 participantes asistieron a cada reunión en todas las seis escuelas; un total de 230 padres ILI participaron en el estudio. De éstos, aproximadamente el $60 \%(n=138)$ se identificaron como indígenas. Muchas comunidades ILI no son receptivas a los forasteros; por lo tanto, se realizaron entrevistas profundas con solo 30 participantes cuyos países de origen (México, El Salvador y Guatemala) fueran representativos de los tres grandes grupos en la muestra del estudio. Las comunidades identificadas en el estudio fueron las indígenas de México (Otomí, Náhuatl, Maya, Zapoteco, Mixteco y Tzotzil), incluyendo El Salvador (pipiles, una población casi extinta) y Guatemala (Quiché y Kaqchikel), entre otros. En general, hubo más de 17 idiomas indígenas entre los 230 participantes. En cuanto a la educación en sus países de origen, 55\% había reportado tener por lo menos alguna educación formal (30\% K-12, 25\% superiores) y $45 \%$ reportó no tener educación formal. Para los propósitos de este artículo, los temas más recurrentes o las experiencias de las mujeres latinas indígenas se utilizan para ilustrar temas comunes entre los entrevistados.

\section{Camaleonas Guerreras: Pedagogías de Mujeres Indígenas Latinas}

Ninguna de las mujeres que participaron en este estudio pudo volver a casa - aproximadamente el 90\% eran inmigrantes indocumentados en Estados Unidos. Sin embargo, todos mantuvieron estrechas relaciones personales y políticas con sus regiones

\section{Result from Demographic Data}

The demographic survey revealed participants country of origin, language spoken, and nationality. Participants had been living in the US for an average of 10.88 years $(S D=8.20)$ and were from a wide variety of countries of origin including Honduras $(n=15)$, El Salvador $(n=40)$, Guatemala $(n=50)$, Mexico $(n=$ 120), and other Central and South American countries $(n=5)$. Between 20 and 30 participants attended each meeting in all six schools, with a total of $230 \mathrm{ILI}$ parents in the study. Of these, roughly 60\% $(n=138)$ identified as indigenous. Many ILI communities are not receptive to outsiders; therefore, indepth interviews were conducted with just 30 participants whose countries of origin (Mexico, El Salvador and Guatemala) were representative of the three largest groups in the study sample. Indigenous communities identified in the study included those from Mexico (Otomí, Náhuatl, Maya, Zapoteco, Mixteco, and Tzotzil), El Salvador (Pipil, an almost extinct population), and Guatemala (Quiché and Kaqchikel), among others. Overall, there were over 17 indigenous languages spoken among the 230 participants. In terms of education in their countries of origin, $55 \%$ reported at least some formal education (30\% K-12, $25 \%$ higher education) and $45 \%$ reported no formal education. For the purposes of this paper, the most recurring themes or experiences of Latina indigenous women are used to illustrate common themes among those interviewed.

\section{Chameleons Warriors: Pedagogies of Indigenous Latina Immigrant Women}

None of the women who took part in this study were able to go back home-about 90 percent were undocumented immigrants in the United States. Yet, they all maintained close personal and political connections with their home regions while living in the 
de origen mientras vivían en los Estados Unidos. Este hallazgo es consistente con la investigación antropológica y sociológica que considera a la transnacionalidad como una forma de morfología social (Vertovec, 1999), con formaciones sociales que sobrepasan las fronteras físicas. Como se ha señalado en otros estudios (Guerra, 1998; Sanchez \& Machado-Casas, 2009), los participantes son capaces de personificar múltiples identidades tanto para mantener sus culturas y para sobrevivir como inmigrantes en Estados Unidos mediante el uso de estrategias y habilidades que pasan a través de las fuertes redes sociales de una familia inmigrante a otra. Además, cuando se combina con el poder del internet, esta estructura social fuerte crea un ambiente donde los inmigrantes ya no necesitan mover físicamente a través de fronteras con el fin de ser transnacional. Sin embargo, las mujeres indígenas en el presente estudio promulgaron lo que Machado-Casas (2009) Ilama la pedagogía del camaleón, que es la

capacidad de transmitir estrategias multipropósito y de múltiples situaciones dentro de una red social transnacional que transforma a los inmigrantes en los maestros del arte de la supervivencia y la invisibilidad en los Estados Unidos, promulgando la pedagogía del camaleón (Pedagogía del camaleón). Esta pedagogía, personificada por inmigrantes latinos y latinas indígenas como la capacidad de cambiar, transformar y disfrazarse, es una habilidad esencial para vivir, convivir y participar en múltiples transacciones diarias, socio-cultural y lingüísticas. (p. 95)

Porque las mujeres son a menudo los guardianes en el hogar, sirven con frecuencia como el primer escudo de su familia y los niños. En su investigación con los indígenas Oaxaqueños en Oregon, Stephen (2007) destacó que debido a que los inmigrantes viven bajo un estado de vigilancia constante, se ven obligados a cambiar, transformarse y convertirse en lo más invisible posible, dada la racializaciòn de los latinos bajo las actuales leyes anti-inmigrantes. Según lo observado por Urrieta (2009), los participantes en este estudio también emplean transas, un término español de connotaciones negativas; se utiliza para describir practicas no tradicionales o marginal. Transas significa literalmente las transacciones (negocios), que en el conocimiento popular mexicana son estratégicas y comunes, sin embargo generalmente son clandestinas prácticas utilizadas por personas
United States. This finding is consistent with anthropological and sociological research that views transnationality as a form of social morphology (Vertovec, 1999), with social formations spanning physical borders. As noted in other studies (Guerra, 1998; Sanchez \& Machado-Casas, 2009), participants are able to switch among multiple identities both to maintain their cultures and to survive as immigrants in the United States by using strategies and skills passed through strong social networks from one immigrant family to another. Furthermore, when coupled with the power of the internet, this strong social structure creates an environment where immigrants no longer need to physically move across borders in order to be transnational.

Yet, indigenous women in this study enacted what Machado-Casas (2009) called the pedagogy of the chameleon, which is the

\begin{abstract}
ability to pass on multisituational, multipurpose strategies within a transnational social network that transforms immigrants into teachers of the art of survival and invisibility in the United States, enacting the pedagogía del camaleón (pedagogy of the chameleon). This pedagogy, embodied by Latino and Indigenous Latino immigrants as the ability to change, shift, and disguise, is essential to their abilities to live, coexist, and take part in multiple daily socio-cultural and linguistic transactions. (p. 95).
\end{abstract}

Because women are often the caretakers in the home, they frequently serve as the first shield for their family and children. In her research with indigenous Oaxacans in Oregon, Stephen (2007) stressed that because immigrants live under a constant state of surveillance, they are forced to change, shift, and become as invisible as they can, given the racialization of the Latino under current anti-immigrant laws. As noted by Urrieta (2009), participants in this study also employed transas, a Spanish term with negative connotations used to describe non-traditional or fringe practices. Transas literally means transactions (dealings), which in Mexican folk knowledge are strategic and common, yet usually clandestine practices used by people with less power to subvert, survive, or get by in the system. By using these calculated multilingual transnational movements or transas (dealings), ILI women create survival strategies which become pedagogías that facilitate life as multilingual camaleónas in the United States; these skills not only 
con menos poder para subvertir, sobrevivir, o bien llevarse en el sistema. Mediante el uso de estos movimientos transnacionales multilingües calculados o transas (relaciones), las mujeres ILI crean estrategias de supervivencia que se convierten en pedagogías que facilitan la vida como camaleónas multilingüe en Estados Unidos; estas habilidades no sólo permiten interacciones exitosas en los Estados Unidos, sino que son utilizadas como escudos de vida (protectores) contra amenazas dirigidas a ellas y especialmente a sus familias. Para las mujeres camaleonas, es un escudo útil para la guerra que es necesario simular dentro y fuera de la casa como inmigrantes en Estados Unidos. De esta manera las guerreras camaleonas están construyendo un legado de supervivencia contra prácticas hegemónicas promulgadas contra ellas y sus familias que han llevado a años de "inferioridad interiorizado que es un subproducto heredado de la colonización y el genocidio. Los ILIs combaten la dominación blanca manteniendo conscientemente su Indignidad vivo a través de prácticas que ayudan a mantener sus culturas y evitar la extinción"(pág. 93). Están en la primera línea de defensa.

Las mujeres que participaron en el estudio identificaron dos temas pedagógicos principales: (a) murallas en las fronteras (muros en la frontera) o accesos en su vivir diario que los obliga a crear identidades fluidas para facilitar la supervivencia física, social y cultural (Machado-Casas, 2009b); y (b) herramientas de camaleonas guerreras (herramientas de mujeres guerreras camaleón), o disfraces que emplean múltiples lenguas y culturas para simular identidades fluidas de supervivencia y protección y redefinir la movilidad transnacional para ellas y sus familias.

\section{Las Murallas Fronterizas (muros en la fron- tera): obstáculos, giros y sitios de opresión}

Todas las mujeres participantes del estudio coincidieron en que dos lugares o sitios son importantes cuando viven como inmigrantes en Estados Unidos. Los "sitios de supervivencia crítica" identificados por los participantes como sitios de opresión y dolor que a menudo son difíciles de infiltrar, aun así representan la primera línea de combate para mujeres inmigrantes que sirven como escudos para sus familias. Las mujeres identificaron dos sitios importantes de enable successful interactions in the United States, but are used as life shields (protectors) against harm aimed at them, and particularly their families. For chameleon women, it is a purposeful shield for the war that they have to enact both in and out of the home as immigrants in the United States. In this way the camaleónas gurerras are building a legacy of survival against hegemonic practices enacted against them and their families that have lead to years of "internalized inferiority that is an inherited byproduct of colonization and genocide. ILIs combat white dominance by consciously keeping their Indiginidad alive through practices that help maintain their cultures and avoid extinction" (p. 93). They are the first line of defense.

Women who participated in the study identified two main pedagogical themes: (a) murallas en las fronteras (walls in the border) or gateways in their everyday lives that that force them to create fluid identities to facilitate physical, social and cultural survival (Machado-Casas, 2009b); and (b) herramientas de camaleónas guerreras (tools of warrior chameleon women), or disguises that employ multiple languages and cultures to enact fluid identities of survival and protection and to redefine transnational mobility for themselves and their families.

\section{Walls in the Border: Obstacles, Turns and Sites of Oppression}

All the women who participated in this study agreed that two places or settings are important when living as immigrants in the US. The "critical survival settings" identified by participants are sites of oppression and pain that are often difficult to infiltrate, yet they are first line of combat for immigrant women who serve as shields for their families. Women identified two major critical survival settings: schools and the surrounding community. 
supervivencia crítica: las escuelas y la comunidad circundante.

Las Escuelas. Todas las mujeres que participaron en este estudio experimentaron múltiples encuentros difíciles con escuelas y funcionarios de las escuelas, incluyendo profesores, a veces. Es un hecho bien conocido que la educación puede mejorar la capacidad de salir adelante. Las Investigaciones han demostrado consistentemente que los niños aprenden mejor cuando sus padres participan activamente en su aprendizaje (Delgado-Gaitán, 1990). Esto era un hecho conocido para estas mujeres que de inmediato se integraron en las escuelas poco después de su llegada a los Estados Unidos. Maria explicó:

\footnotetext{
Llegué a la escuela e inmediatamente fui tratada como una forastera. Se me hizo preguntas que no sabía responder y me entregaron formatos que no sabía cómo llenar. Al principio fue muy difícil. Fui honesta y les dije que el español no era mi primer idioma y no me creyeron. Se rieron y me dejaron allí. Siguieron con su tarea y me quedé ahí hasta que me fui.
}

Aunque las investigaciones consistentemente han reportado que hay una falta de comprensión de las escuelas sobre la diversidad de las familias inmigrantes (Nieto, 2009), para las familias indígenas este tema se complica por el hecho de que muchos ni siquiera comprenden que una persona puede ser "Latino" y no hablar español. Ofelia tuvo una experiencia similar, pero en su caso, las cosas se complicaron.

\footnotetext{
Fui a la escuela y me encontré con la profesora de segundo grado. Ella sonrió y me preguntó de dónde era. Le dije que era de Puebla y me preguntó de dónde. Entonces me pregunto a qué grado había llegado mi hijo, le dije que al segundo grado. Entonces me dijo que mi hijo parecía tener la lectura del nivel de un pre-kínder y no parecía haber completado el segundo grado y que decía cosas raras. Le expliqué que yo era Otomí y que era la lengua que hablamos. Entonces se enojó realmente y dijo: "ahora no sólo tengo que lidiar con los niños mexicanos sino también con los indios - ¿Qué voy a hacer?" Dijo ella, “lo siento no sé si puedo trabajar con tu hijo. ¿Por qué no le enseñas a tu hijo inglés? Tú eres la madre y usted es responsable de su éxito. Tienes que enseñarle el inglés. Hasta que lo hagas, no seré capaz de ayudar." Me sentí humillada.
}

Ofelia fue personalmente atacada por esta maestra quien le dijo que como la madre, la mujer en la familia, era su responsabilidad de asegurar que su hijo alcanzara el éxito. En una conversación posterior, añadió:
Schools. All of the women who participated in this study experienced multiple difficult encounters with schools and school officials, including teachers, at times. It is a well-known fact that education can improve one's ability to get ahead. Research has consistently proven that children learn well when their parents are actively involved in their learning (Delgado-Gaitán, 1990). This was a known fact for these women who immediately went to school soon after their arrival in the United States. Maria explained:

\footnotetext{
I got to the school and I was immediately treated as a stranger. I was asked questions I did not know how to answer and given forms that I did not know how to fill. At the beginning it was really hard. I was honest and I told them that Spanish was not my first language and they did not believe me. They laugh and just left me there. They went on with their task and I just stood there until I left.
}

Although research has consistently reported that there is a lack of understanding from schools about the diversity of immigrant families (Nieto, 2009), for indigenous families this issue is complicated by the fact that many do not even understand that a person can be "Latino" and not speak Spanish. Ofelia had a similar experience, but in her case things got complicated:

I went to the school and I met the second grade teacher. She smiled, and asked me where I was from. I told her that I was from Puebla and she asked me where from. She then asked me what grade my son went to, and I told her the second grade. She then told me that it seemed to her that my son had a pre$\mathrm{K}$ reading level and he did not seem like he had completed second and that he kept saying some weird stuff. I explained that I was Otomí and that it was the language we spoke. She then got really angry and said, "Now I not only have to deal with just Mexican kids but also with Indians-what am I going to do?" She said, "I'm sorry I just don't know if I can work with your kid. Why don't you teach your kid English? You are the mother and you are responsible for his success. You need to teach him English. Until you do, I will not be able to help." I felt humiliated.

Ofelia was personally attacked by this teacher who told her that as the mother, the woman in the family, it was her responsibility to ensure that her child was successful. In a later conversation, she added: 
Creo que fue la primera vez que me di cuenta de que en las escuelas, las mujeres son las que cuentan, las que tienen importancia. En todo ese año la maestra no preguntó ni una sola vez por mi esposo. Todo el peso de la responsabilidad fue puesta en mí. Cuando le dije a la profesora que mi marido se ocuparía de algunas de las cuestiones dijo, "he oído que los hombres de su comunidad son agresivos. No se sienta obligada a hacer esto. Podemos ayudar".

Ofelia se dio cuenta de que todo el peso del éxito fue colocado en ella como madre y que la profesora pensó que ella era la que lidiaba con lo pertinente a la escuela porque se vio "obligada" por su marido a hacerlo. Esto la hizo sentir como si ella no tenía ninguna autonomía en la toma de decisiones de su hogar.

Joaquina describe experiencias similares con las escuelas:

No tengo mucha educación formal. Solo cursé el tercer grado pero sé mucho. He aprendido de la vida. Soy callada, pero cuando hablo es con certeza. Cuando fui por primera vez a la escuela, la maestra ya había oído que yo hablaba Quiché y luego procedió a hablarme muy despacio en español como si yo era un bebé. Decía cosas como, "Probablemente no sabes esto," o "Usted probablemente no tiene escuelas de dónde vienes", o "Yo entiendo si no lo sabes. Esto no es normal para alguien como tú..."

Puesto que Joaquina era indígena y tenía poca educación formal, la profesora inmediatamente la categorizó como "ignorante". La profesora asume automáticamente que no tenía conocimiento o no podía relacionarse con lo que ocurría en las escuelas. Se convirtió en una pizarra en blanco y un "trabajo" para ser arreglado por un profesor. Machado-Casas (2010, manuscrito inédito) escribió que muchas de estas mujeres inmigrantes son víctimas de la "pedagogía de marioneta" simplemente porque se han identificado como indígenas. A menudo, nunca se les dice lo que ocurrirá, cómo ni cuándo. Son tratadas como marionetas que forman parte de una orquestada danza frente a una muralla (pared) diseñada para denegarles el acceso.

Comunidad circundante. Para entender las distintas experiencias de mujeres ILI, debemos empezar por reconocer las diferencias regionales entre grupos diferentes de inmigrantes. Es vital reconocer que aunque el término latina/o es más inclusivo, también sirve como una forma de seguir ocultando comunidades marginalizados tales como los inmigrantes in-
I think that was the first time that I realized that in schools, we women are the ones that count, that matter. That entire year that teacher did not ask for my husband once. The weight of the responsibility was all put on me. When I told the teacher that my husband would deal with some of the issues she said, "I heard that the men in your community are aggressive. Don't feel forced to do this. We can help."

Ofelia realized that all the weight of success was placed on her as a mother and that the teacher thought that she was the one dealing with the school because she was "forced" by her husband to do so. This made her feel as if she did not have any autonomy in the decision making of her home.

Joaquina described similar experiences with schools:

I do not have a lot of formal education. I went only to third grade but I do know a lot. I learned from living. I'm quiet, but when I speak I mean what I say. When I first went to the school, the teacher had already heard that I spoke Quiché and she then proceeded to speak very slowly in Spanish as if I was a baby. She said things like, "You probably don't know this," or "You probably don't have schools where you come from," or "I understand if you do not know. This is normal for someone like you..."

Since Joaquina was indigenous and had little formal schooling, the teacher immediately categorized her as "ignorant." The teacher automatically assumed that she did not know or could not relate to what was happening in schools. She became a blank slate and a "job" for a teacher to fix. Machado-Casas (2010, unpublished manuscript) wrote that many of these immigrant women are victims of the "puppet pedagogies" simply because they have identified as indigenous. Oftentimes, they are never told what will happen, how or when. They are treated like puppets who are part of an orchestrated dance in front of a muralla (wall) designed to deny access to them.

Surrounding community. In order to understand the distinct experiences of ILI women, we must begin by recognizing regional differences between different immigrant groups. It is vital to recognize that although the term Latina/o is more inclusive, it also serves as a way to continue to ocultar marginalized communities such as indigenous immigrants. When

[ 34 ] MARGARITA MACHADO-CASAS 
dígenas. Cuando se utiliza el término latina/o, uno tiene que ser consciente de su uso y las formas en las que, en ausencia de la diferenciación, uno puede repetir los ciclos de la colonización. En el caso de las mujeres indígenas en este estudio, el uso de este término sin una distinción sólo sirve para perpetuar la invisibilidad y la opresión de las comunidades históricamente marginadas.

Las prácticas discriminatorias y opresivas experimentadas por muchos Latinos indígenas a menudo comienzan en sus países de origen, donde se perpetúan prácticas racistas por sus semejantes no indígenas "Latino". Cuando llegan a los Estados Unidos, estas prácticas discriminatorias migran con ellos y son a menudo repetidas (Machado-Casas, 2009). Por lo tanto, muchos inmigrantes indígenas sienten la necesidad de ocultarse tanto de los blancos como de los americanos latinos (o inmigrantes), y enseñar a sus hijos a protegerse de las mismas conductas xenófobas que experimentaron en sus países de origen, que ahora irónicamente también han emigrado con ellos a los Estados Unidos (Machado-Casas, 2009). Según las mujeres en este estudio, estas formas repetidas de opresión estaban muy vinculadas al trato que recibieron en sus lugares de origen de parte de sus connacionales. Juanita dijo:

Fui a la tienda y la cajera escuchó que le hablaba a mis hijos en mi idioma nativo [Otomí] y dijo, "Escuche no esperes ser tratada de manera diferente - todavía eres un indio aquí." Esto me enfureció. Fui trasladada de vuelta a las formas de trato recibido en mi lugar de origen. Realmente pensé que las cosas serían muy diferentes aquí.

Juanita fue detectada, "encontrada" y fue maltratada por un compañero Latino que probablemente había sido tratado del mismo modo. Como mujeres indígenas, no sólo tienen que estar vigilante de los "blancos" sino también de otros inmigrantes (incluyendo compañeros Latinos) que pueden haber traído creencias xenófobas con ellos. Otra mujer indígena, Fernanda, expresó preocupación por lo que la gente pensaba de ella cuando estaba trabajando:

La gente asume inmediatamente que somos tontos e ignorantes. Sí, somos diferentes. Pero sabemos lo que queremos. Muchos de nosotros no somos callados; somos respetuosos, y esto es tomado fuera de contexto muchas veces. Tengo un trabajo de limpieza en un hotel. Una semana después de que me contrataron, la señora que contrata dijo, "si hubiera sabido que podía haberte pagado menos y no te quejabas, lo habría hecho. using the term Latina/o, one needs to be aware of its usage and the ways in which, in the absence of differentiation, one can repeat cycles of colonization. In the case of the indigenous women in this study, the use of this term without distinction only serves to perpetuate the invisibility and oppression of historically marginalized communities.

The discriminatory and oppressive practices experienced by many indigenous Latinos often begin in their countries of origin, where racist practices are perpetuated by their non-indigenous "Latino" peers. When they arrive in the United States, these discriminatory practices migrate with them and are often repeated (Machado-Casas, 2009). Therefore, many indigenous immigrants feel the need to ocultarse from both white and Latino Americans (or immigrants), and teach their children to protect themselves from the same xenophobic behaviors they experienced in their countries of origin, which have now ironically also migrated with them to the United States (Machado-Casas, 2009). According to the women in this study, these repeated forms of oppression were very much linked with the treatment they received back home from fellow nationals. Juanita said:

I went to the store and the cashier heard that I was speaking to my children in my native language [Otomí] and she said, "Listen don't expect to be treated differently-you still an Indian here." This angered me! I was taken all the way back to the ways I was treated back home. I really thought that things would be a lot different here.

Juanita was spotted, "found" and was mistreated by a fellow Latina who had probably been treated the same way. As indigenous women, they not only have to watch out for "whites" but also for other immigrants (including fellow Latinos) who may have brought xenophobic beliefs with them. Another indigenous woman, Fernanda, expressed concern about what people thought about her when she was working:

People immediately assume we are dumb and ignorant. Yes, we are different. But we know what we want. Many of us are not quiet; we are respectful, and this is taken out of context many times. I got a job cleaning a hotel. A week after I got hired, the lady that hired said, "If I would have known I could have paid you less and you would not complain, I would have done it. After all, that is what you are used to right? At least it would have been more than what you make back home." I 
¿Después de todo, a eso es lo que estás acostumbrada, cierto? Por lo menos hubiera sido más de lo que ganas en tu lugar de origen." Pensé, ¿qué le hace pensar que aceptaría menos? ¿Por qué ella asumiría que tengo menos valor que una mujer mexicana regular? Eso me enfureció y encontré otro trabajo. En este nuevo trabajo aprendí, y ahora hago las cosas de manera diferente.

La narrativa de Fernanda enfoca un pensamiento que era muy común en el trato de muchas mujeres indígenas: la idea de que porque eran indígenas tenían menos valor que las mujeres latinas inmigrantes no indígenas. Aunque no fue expresado en las mismas palabras, todas las mujeres discutieron cómo su valor y lo que deberían estar dispuestas a tolerar, fue cambiado al minuto que otros descubrieran que eran indígenas. También señala que como mujeres indígenas tienen autonomía y sí expresan sus creencias; contrastando los estereotipos sobre las mujeres indígenas de ser sumisas. Explicó que su silencio o "estar calladas" es simplemente por respeto, y que es una suposición importante que se hace de ellas. Además, después de ser tratadas de tal manera han aprendido a comportarse de forma diferente, para moverse dentro y fuera de los espacios con el objetivo de poder sobrevivir.

\section{Herramientas Transnacionales de Camaleó- nas Guerreras}

Como se señaló anteriormente, Delgado-Gaitán (1990) nos hizo conscientes de los múltiples estereotipos que sitúan a las familias latinas como pasivas y despreocupadas por la educación de sus hijos. (Gibson, Gándara \& Koyama, 2004; Vásquez, PeaseAlvarez \& Shannon, 1994). Estas enseñanzas de la educación en la casa, con frecuencia realizadas por mujeres, (Valdés, 1996) son a veces más valiosas para muchos de estos padres. Esto es particularmente cierto para las mujeres inmigrantes cuyos maridos pasan muchas horas en el trabajo, dejándolas con la mayor parte de la responsabilidad en casa. Esta responsabilidad, junto con el maltrato que se trasladó con ellas a los Estados Unidos ha causado que muchas mujeres inmigrantes indígenas (y otros) traten de proteger a sus familias y ellas mismas del abuso. Los participantes entendieron que es crítico para las mujeres indígenas inmigrantes transmitir este conocimiento con el fin de asegurar: (a) la protección contra aquellos que puedan dañarlos, (b) la super- thought, what makes her think that I would take less? Why would she assume I'm worth less than a regular Mexican woman? It angered me and I found another job. In this new job I learned, and I do things differently now.

Fernanda's narrative speaks to a thought that was very common in the treatment many indigenous women received: the idea that because they were indigenous they were worth less than non-indigenous Latino immigrant women. Although not said in the same words, all the women discussed how their worth and what they should be willing to tolerate changed the minute others discovered they were indigenous. She also points out that as indigenous women they do have autonomy and do express their beliefs, unlike stereotypes about indigenous women being submissive. She explained that their silence or "being quiet" is simply out of respect, and that it is an important assumption that it is made about them. Furthermore, after being treated in such way they have learned to behave differently, to move in and out of spaces in order to survive.

\section{Transnational Tools of Warrior Chameleon Women}

As noted earlier, Delgado-Gaitán (1990) made us aware of the multiple stereotypes that situate Latino families as passive and not caring about their children's education. (Gibson, Gándara, \& Koyama, 2004; Vásquez, Pease-Alvarez, \& Shannon, 1994). Frequently carried out by women, it is these teachings of educación en la casa (Valdés, 1996) which are at times most valuable for many of these parents. This is particularly true for immigrant women whose husbands spend many hours at work, leaving them with most of the home repsonsibilities. This responsibility, coupled with the mistreatment that has followed them to the United States has caused many indigenous immigrant women (and others) to try to shield their families and themselves from abuse. Participants understood that it is critical for indigenous immigrant women to pass on this knowledge in order to ensure: (a) protection from those who may harm them, (b) survival as indigenous immigrant women and families in the United States, and (c) transmis-

[ 36 ] MARGARITA MACHADO-CASAS

SIPS - PEDAGOGIA SOCIAL. REVISTA INTERUNIVERSITARIA [1139-1723 (2014) 23, 21-44] TERCERA ÉPOCA 
vivencia como mujeres indígenas inmigrantes y familias en los Estados Unidos y (c) la transmisión de su cultura indígena y tradiciones en los Estados Unidos. Se identificaron tres maneras en las que transmiten estos conocimientos: la política de la filogenia orgánica, disfraz multilingüe y multicultural.

Machado-Casas (2009) teorizó sobre la capacidad de mantener y transmitir conocimientos. Al escribir sobre la política de la filogenia orgánica, explicó:

El término filogenia se refiere al desarrollo evolutivo y la historia de un grupo u organismo particular; se expande en la secuencia de eventos involucrados en el desarrollo de un grupo en particular. $\mathrm{Y}$, aunque este término se ha utilizado en biología para describir a los organismos vivos en sus procesos de vida, como organismos vivos, los seres humanos también siguen cierto desarrollo y crecimiento evolutivo que están directamente vinculadas a la historia y las experiencias pasadas. El término orgánico significa vivo, crecimiento natural, pertinente a figuras y formas encontradas en la naturaleza de las interacciones en la vida diaria. Los padres indígenas en este estudio ejercen la política de la filogenia orgánica porque toman su historia pasada y el conocimiento como pueblos indígenas y transmiten este conocimiento acumulado a sus hijos a medida que avanzan a través de los procesos de crecimiento y evolución, incluyendo las más recientes experiencias de crecer como inmigrantes indígenas transnacionales en los Estados Unidos. Usando sus experiencias pasadas de su país de origen y sus experiencias como inmigrantes en Estados Unidos, estos padres indígenas son capaces de transmitir a sus hijos - de una manera natural y orgánica - la necesidad de ser capaces de atravesar múltiples espacios y lenguajes y las maneras en que pueden sobrevivir como pueblos indocumentados en los Estados Unidos. (p. 87)

En alguna medida, el tema de la política de la filogenia orgánica fue abordado por todas las madres. Juanita dijo: en este país, somos camaleones y guerreras. Hemos aprendido que tenemos que adaptarnos para poder sobrevivir, pero lo más importante es que somos el foco de lo que será el futuro de nuestros hijos. Es nuestro deber asegurar de que sepan cómo ser camaleones, también.

Juanita explicó este importante reconocimiento hecho por muchas mujeres indígenas que viven como inmigrantes en Estados Unidos. Se involucran en un proceso de pensamiento calculado y toman acciones deliberadas para asegurarse de que sus hijos también aprendan a sobrevivir. $Y$ entienden que los miembros de la familia, especialmente sus hijos, necesitan este conocimiento para sobrevivir como personas indígenas en los Estados Unidos. Fernanda elaboró:

Desde el momento en que nació mi hija supe que tenía que enseñarle cómo comportarse en diferentes escenarios, como actuar de manera diferente dependiendo de cómo percibe el trato que recibe. He tenido que enseñarle que tenía que ser muchas cosas a la vez. Que tenía que tener cuidado y prote- sion of their indigenous culture and heritage in the United States. They identified three ways in which they pass on such knowledge: the politics of organic phylogeny, multilingual disguise, and multicultural disguise.

Machado-Casas (2009) theorized on the ability to maintain and transmit knowledge. When writing about the politics of organic phylogeny, she explained:

The term phylogeny refers to the evolutionary development and history of a particular group or organism; it expands on the sequence of events involved in the development of a particular group. And, although this term has been used in biology to describe living organisms in their life processes, as living organisms, human beings also follow a certain development and evolutionary growth which is directly tied to one's history and past experiences. The term organic means living, natural growth, pertaining to shapes and forms found in nature within interactions in daily life. Indigenous parents in this study practice the Politics of Organic Phylogeny because they take their past history and knowledge as indigenous peoples and transmit this cumulative knowledge to their children as they move through the processes of growth and evolution, including the most current experiences of growing up as transnational indigenous immigrants in the US. Using their past experiences from their country of origin, and their experiences as immigrants in the US, these indigenous parents are able to transmit to their children-in a natural and organic way-the need to be able to navigate multiple spaces and languages, and the ways in which they can survive as undocumented peoples in the US. (p. 87)

The politics of organic phylogeny were described by all of the mothers in some way. Juanita said: In this country, we are chameleons and warriors. We learned that we have to adapt in order to survive, but most importantly that we are the center of what will be the future of our children. It is our duty to make sure they know how to be chameleons, too.

Juanita explained the purposeful acknowledgement made by many indigenous women while living as immigrants in the United States. They engage in a process of calculated thought and take deliberate actions to ensure that their children also learn how to survive. And, they understand that all family members, especially their children, need this knowledge in order to survive as indigenous persons in the United States. Fernanda elaborated:

From the moment I had my child I knew I had to teach her how to behave in different settings, how to act in a different way depending on how she perceived she was treated. I had to teach her that she had to be many things all at once. That she had to be careful, and protect herself always. I tell her somet- 
gerse siempre. Le digo algo, "Tendrás que actuar como una mexicana regular, alguien que no es de nuestro pueblo". Le dije, “Tu sabrás, pero tienes que entender que mucha gente no nos entienden o no nos quieren.

Más adelante expresó que esto era algo que tenía que hacer con frecuencia y que a veces ella actuó de esa manera también. Continuo diciendo:

Le digo que no le estoy pidiendo que haga algo que no haya hecho yo también. Que muchas veces he tenido que actuar diferente o como "otra persona". Es la manera que utilizamos para poder recibir mejor trato. Que es triste, pero también empodera saber, aunque sea solo por dentro, que se puede ser muchas cosas diferentes a la vez y ganar.

Parte de esta enseñanza es que el problema no es necesariamente ellos, sino otras personas que no entienden quiénes son ellos. Esto ayuda a sus hijos a mantener una imagen positiva y sirve como una explicación preliminar de por qué deben actuar de esta manera. Ella también discutió la idea de moldear este comportamiento para que entiendan que también tienen que comportarse de esta manera, $y$ que no es inusual. Más específicamente, las indígenas inmigrantes latinas enseñan a sus hijos a ser lo más natural posible con otros (es decir, los americanos blancos y Latinos no indígenas), fingir ser el otro, adquirir bienes como los otros y sobrevivir en los Estados Unidos como los otros. La política de la filogenia orgánica es la forma en que los padres enseñen a sus hijos a vivir en múltiples mundos - a ser transnacionales y a sobrevivir en diferentes contextos, en diferentes mundos fuera de sus casas.

Camuflaje Multilingüe. Las mujeres inmigrantes indígenas que participaron en este estudio se identificaron fuertemente con un idioma nativo que no era español o inglés. Todas hablaban lenguas indígenas que en la mayoría de los casos es la primera señal de formación de la identidad e identificación. Estas mujeres vieron el idioma como un indicador de identidad, algo que no podían perder. Es probable que estarían de acuerdo con otras mujeres como Anzaldua (1987) quien dijo: "Yo soy mi idioma" (p. 59). Aunque los participantes en este estudio no residían en una ciudad fronteriza, creían también que perder sus lenguas sería como perder su identidad y su capacidad de ser transnacional. Iza, una mujer indígena Otomí de 28 años de edad de Pahuatlan, México, dijo: hing, "You will have to act like a regular Mexican, someone who is not from our town." I tell her, "You will know, but you need to understand that a lot of people don't understand or like us."

She went on to say later that this was something she had to do frequently and that sometimes she acted that way as well. She continued:

I tell her that I'm not asking her to do something I do not do myself. That at times I have had to act differently or like "someone else" many times. That it is a way that we use so we can get better treatment. That it is sad, but also empowering to know that you can be many different things at once and win, even if it is just inside.

Part of this teaching that the problem is not necessarily them, but other people who do not understand who they are. This helps their children maintain a positive self-image, and serves as a preliminary explanation for why they must act this way. She also discussed the idea of modeling this behavior so they understand that they too will have to behave in this way, and that it is not uncommon. More specifically, indigenous Latino immigrants teach their children how to be as natural as possible with the other (i.e., white Americans and non-indigenous Latinos), to pass as the other, to acquire goods as the other, and to survive in the United States as the other. The politics of organic phylogeny are the ways in which parents teach their children to live in multiple worlds-to be transnationals and to survive in different settings, in different worlds outside their homes.

Multilingual camouflage. Indigenous immigrant women who participated in this study strongly identified with a native language other than Spanish or English. They all spoke indigenous languages that in most cases are the first sign of identity formation and identification. These women saw language as an identity marker, something they could not afford to lose. They would likely agree with other women like Anzaldua (1987) who said, "I am my language" (p. 59). Although participants in this study did not reside in a border town, they also felt that losing their languages would be like losing their identities and ability to be transnational. Iza, a 28-year-old indigenous Otomí woman from Pahuatlan, Mexico, said:

[ 38 ] MARGARITA MACHADO-CASAS 
Siento que no puedo perder mi lengua Otomí. Estoy perdida si ella. Es la lengua que utilizo para sentir, amar, cuidar y en muchos casos pensar. Pero también sé que necesito el español para poder hablar con todas las demás personas de México o con los que hablan el español y el inglés para poder hacerles pensar que he estado aquí durante un tiempo y así evitar ser asediada.

Para Iza, su lengua nativa es la más importante, la que ella no puede permitirse perder. Sin embargo, también reconoce la importancia de hablar el español y el inglés como herramientas para la supervivencia, el español para poder socializar y el inglés para que pueda ocultarse. Para Iza, hablar los tres idiomas era imprescindible para la supervivencia - un tema que ha sido investigado ampliamente por los científicos sociales que sostienen que el lenguaje es el eje principal y el medio por el cual entendemos la cultura (Anzaldúa, 1987; Baquedano-López, 1997; Ek, 2005; González, 2001; Zentella, 1997, 2005). El uso de varios idiomas en situaciones múltiples es un buen ejemplo de una herramienta del coyote (Machado-Casas, 2009) facilitando la "entrada y participación en las fronteras interculturales y lingüísticas" (pág. 20). La elección del idioma para Iza, al igual que para muchos otros inmigrantes en la misma situación, era consciente, deliberada y dependiente de la circunstancias.

María, una mujer Quiché de Guatemala, siente que ser multilingüe le permitió acceso a diferentes entornos sociales, incluyendo aquellos donde ella generalmente era excluida:

Mi lengua me permite comunicarme con los que me rodean. Sí, es el centro de mí ser. Al ser capaz de comunicarme en Quiché, puedo hacer muchas cosas que me permiten estar activa en mi comunidad... También, tener la capacidad de comunicarme con personas de habla español, puedo...bueno...a veces ser tratada como una persona regular... una guatemalteca regular, que es algo importante porque sin eso no tendría posibilidad de tener tan siquiera un buen trato en los[almacenes administrado por inmigrantes mexicanos], no sólo en mi país pero también aquí [en los Estados Unidos]. El Ingles...bueno.. Sé un poquito...suficiente para poder decir lo que necesito y para que me entiendan mis jefes. [Los idiomas son] importantes, porque tenemos que ser capaces de hacer cosas aquí. ..Necesito poder trabajar aquí [en los Estados Unidos] y ayudar a mi pueblo natal en Guatemala. Necesito de todos los idiomas dependiendo de las circunstancias. Si no puedo utilizar uno de estos entonces eso significa que probablemente no seré capaz de hacer lo que debo hacer porque pienso que las personas nos tratarán diferentes o percibo "enojo" (hostilidad) hacia mis hijos o hacia mí.
I feel that I cannot lose my Otomí language. I'm lost without it. It is the language I use to feel, love, care, and in many cases think. But I also know that I need the Spanish to be able to talk to all the other people from Mexico or who speak Spanish, and the English to be able to make them think that I have been here for a while so they would leave me alone.

For Iza, her native language was the most important, the one she could not afford to lose. However, she also recognized the importance of speaking Spanish and English as tools for survival - Spanish so she could socialize and English for camouflage. For Iza, speaking all three languages was imperative for survival-a point that has been researched extensively by social scientists who argue that language is the central means and medium by which we understand culture (Anzaldúa, 1987; González, 2001; Zentella, 1997, 2005). The multisituational use of several languages is a good example of a coyote tool (MachadoCasas, 2009) that facilitates "entrance and participation in cross-cultural and linguistic borders" (p. 20). Iza's choice of language, like many other immigrants in the same situation, was conscious, deliberate and situational.

María, a Quiché woman from Guatemala, felt that being multilingual gave her access to different social settings, including those where she usually was ostracized:

My language allows me to communicate with those around me. Yes, it is the center of my being. By being able to communicate in Quiché, I can do many things that allow me to be active with my community. Also, being able to communicate with Spanishspeaking people, I can...well...sometimes be treated like a regular...a regular Guatemalan, which is something important because without that I would not be able to even be treated right at the [grocery store run by Mexican immigrants], not only in my country but also here [in the US]. English...well I know a little...enough to be able to say what I need and for my bosses to understand. [Languages are] important, because we need to be able to do things here...I need to be able to work here [in the US] and to help my hometown in Guatemala. I need all the languages depending on the situation. If I cannot use one of these then that means that I will probably not be able to do what I need to do because I feel that people will treat us differently or if I sense "anger" (hostility) towards my children or me.

Here, Maria provided us with a glimpse of her reality as an ILI woman living in the United States. She explained how using multiple languages provided her access to various social spaces or cultural worlds typically not available to a marginalized indigenous 
Aquí, María nos ofrece un pequeño vistazo de su realidad como una mujer ILI viviendo en los Estados Unidos. Ella explica cómo utilizar varios idiomas ha facilitado su acceso a los diversos espacios sociales o mundos culturales que normalmente no está disponibles para una mujer indígena marginalizada. Emplear lenguajes múltiples le proporciona momentos de aceptación en espacios de poder colonizados en Estados Unidos. Ella reconoce las lenguas que juegan un papel clave en su supervivencia física y social. Juanita también habló sobre su uso del lenguaje para la supervivencia.

Los Idiomas son herramientas utilizadas para la comprensión de las diferencias culturales y lingüísticas en ambientes inhóspitos y para la protección contra abusos sociales y la extinción. Por lo tanto, el multilingüismo rápidamente se convierte en una forma de vida para los ILIs.

Camuflaje multicultural. Los resultados de varios estudios de investigación indican que los inmigrantes ven a los Estados-nación como esencial para la identidad (Massey, 1999; Rouse, 1992, 1989); es decir, los inmigrantes todavía se identifican con sus países de origen. Contrariamente a los resultados de estas investigaciones, sin embargo, los indígenas participantes en este estudio se identifican con sus comunidades indígenas (por ejemplo, Otomí, Quiché) en vez de sus países de origen. Una explicación para esto es una larga historia de marginación experimentada por las comunidades indígenas, tanto en América Latina como en Estados Unidos (Stephen, 2007). En la mayoría de los casos, los miembros de las comunidades indígenas son considerados ciudadanos de segunda clase, "porque" éramos de la aldea y éramos indios. María explicó:

Como mujer Quiché tengo que esconder quien soy. Tengo que protegerme del mismo tipo de abuso que experimenté en mi país por aquellos que eran de Guatemala y por otros que ven a un Quiché y que escuchan Quiché y creen que pueden abusar de nosotros, aprovecharse de nosotros. Que somos ignorantes, que no valemos. Tengo que protegerme a mí mismo y por eso cambio mi manera de actuar, para tener protección. Es por ello que fuera de la casa somos otras personas, somos como otros inmigrantes. Nos vestimos diferentes, hablamos diferente, nos escondemos, nos transformamos cuando salimos.

Viejos prejuicios, sentimientos y creencias antiindígenas emigran a Estados Unidos junto con los in- woman. Employing multiple languages granted her moments of acceptance in colonized spaces of power in the United Sates. She recognized the key role of languages in her physical and social survival. Juanita also elaborated on her use of language for survival.

Languages are tools used for understanding cultural and linguistic differences in inhospitable environments, and for protection against social abuse and extinction. Thus, multilingualism quickly becomes a way of life for ILIs.

Multicultural camouflage. The results of several research studies indicate that immigrants find nationstates to be central to identity (Massey, 1999; Rouse, 1992, 1989); that is, immigrants still identify with their countries of origin. Contrary to those research findings, however, indigenous participants in this study identified with their indigenous communities (e.g., Otomí, Quiché) over their home countries. One explanation for this is a long-standing history of marginalization experienced by indigenous communities, both in Latin America and the United States (Stephen, 2007). In most cases, members of indigenous communities are considered second-class citizens, "because we were from the village and were Indios (Indians)." Maria elaborated:

\footnotetext{
As a Quiché woman I have to hide who I am. I have to protect myself from the same type of abuse I experienced in my country by those who were from Guatemala and by others who see a Quiché and who hear Quiché and think that they can abuse us, take advantage of us. That we are ignorant, that we are not worth it. I have to protect myself and this is why I change the way l act-for protection. That is why outside of the house we are other people, we are like other immigrants. We dress different, we talk differently, we hide, we change when we go out.
}

Anti-indigenous beliefs, sentiments, and old prejudices migrate to the United States along with immigrants. Yet, multilingualism often times is a

[ 40 ] MARGARITA MACHADO-CASAS 
migrantes. Sin embargo, el multilingüismo con frecuencia es una espada de doble filo que permite a estos participantes la capacidad de "pasar" u ocultar, no sólo como una estrategia de supervivencia (como es mencionado anteriormente por María), sino también como uno que ayuda a mantener las estructuras sociales opresivas y hegemónicas. Por lo tanto, las comunidades ILI no sólo luchan con marginación creada por las estructuras de poder en los Estados Unidos, pero también con prejuicios exhibidas por los inmigrantes no indígenas. Los participantes en este estudio fueron adicionalmente marginados en las comunidades de inmigrantes que ya sufrían marginación.

En México, no querían a nosotros los indios (indígenas) a como nos llamaban. Cuando llegamos aquí nos hicimos más mexicanos. Soy mexicano, porque yo nací allí. Pero cuando estaba en México, era Otomí. Aquí, si puedo hablar como una mexicana nadie cuestionará si lo soy o no. Por primera vez, soy vista como una mexicana. (Iza)

La migración puede ampliar el discurso del miedo y odio enfrentada por los ILIs en su lugar de origen. Viven con el legado del genocidio indígena que les ha seguido a través de las fronteras. Para Iza, siendo una guerrera camaleóna le dio las herramientas que necesitaba para disfrazar su indiginidad y formar parte de la sociedad dominante del inmigrante Latino.

Para estas mujeres indígenas ser una camaleóna guerrera fue más que una estrategia social; se convirtió en una forma de vida que se extiende a modelos para criar sus hijos y a relaciones comunitarias. Transmitir la pedagogía del camaleón y enseñar a otros cómo desbloquear los códigos ocultos de la supervivencia y el acceso se ha convertido tanto en una forma de sobrevivir en un ambiente hostil como de preservar la lengua y la cultura indígena.

En los hogares, las identidades, lenguas y culturas nativas son preservadas y vistas como esenciales para la supervivencia de la familia y la comunidad. Fuera del hogar la camaleonalidad (comportamiento del camaleón), es esencial para obtener acceso a recursos y para la integración. $Y$ en lugar de perpetuar un sentimiento de inferioridad interiorizado, otros entendieron que las primeras lecciones comienzan en casa; para algunas comunidades, estas lecciones incluyen aprender a sobrevivir, aprender a reconocer lo que es considerado un espacio "seguro", que cada espa- double-edged sword that allows these participants the ability to "pass" or hide, not only as a strategy for survival (as mentioned by Maria above), but also as one that helps maintain oppressive and hegemonic societal structures. Thus, ILI communities not only struggle with marginalization created by power structures in the United States, but also prejudice exhibited by non-indigenous immigrants. Participants in this study were further marginalized within already marginalized immigrant communities.

\footnotetext{
In Mexico, they didn't like us los Indios (indigenous people) as they would call us, so much. When we got here we became more Mexican. I am Mexican because I was born there. But when I was in Mexico, I was Otomí. Here, if I can talk like a Mexican no one will question if I am or not. For the first time, I pass as a Mexican. (Iza)
}

Migrating can amplify the discourse of fear and hatred ILIs faced at home. They live with the legacy of indigenous genocide that has followed them across borders. For Iza, being a camleóna guerrara gave her the tools she needed to disguise her Indiginidad and become part of the mainstream Latino immigrant society.

For these indigenous women, being a camaleóna guerrera was more than a social strategy; it became a way of life that extends into child rearing practices and community relationships. Teaching others how to unlock the hidden codes of survival and access became both a way of surviving in a hostile environment and preserving indigenous culture and language. Inside the home, native cultures, languages and identities were preserved and seen as essential to family and community survival. Outside the home, camaleónalidad (chameleon-like behavior) was essential to obtaining access to resources and fitting in. And rather than perpetuating an internalized sense of inferiority, others understood that the first lessons begin at home; for some communities, these lessons include learning how to survive - learning what is considered a "safe" space, learning that every space harbors the potential to become "unfriendly" and learning that part of living as an ILI is understanding that one needs to remain vigilant at all times. Rather than succumbing, survival requires a more aggressive approach toward protecting, advancing, and preserving one's language and culture. Being 
cio alberga el potencial para convertirse en "hostil" y aprender que parte de la vida del ILI es comprender que uno debe permanecer vigilante en todo momento. En lugar de sucumbir, la supervivencia requiere un enfoque más agresivo hacia proteger, promover y preservar la lengua y la cultura. Ser un camaleón es el antídoto para vivir una vida sin miedo.

\section{Conclusiones}

Ser camaleónas guerreras es una estrategia de supervivencia que abarca elementos físicos, sociales y culturales que se manifiestan como disfraz multilingüe y de cultura múltiple que permite que se muevan fluidamente a través de múltiples identidades. Enseñando a usar estas herramientas es una manera para que las mujeres ILI ayuden a sus familias a sobrevivir físicamente y socialmente en un mundo donde los pueblos indígenas están condenados al ostracismo, abusados e incluso asesinados. Toman decisiones conscientes dependiendo de las situaciones en términos de lenguaje y comportamiento con el objetivo de integrarse. Muchas mujeres ILI incluso utilizan el lenguaje como camuflaje entre los inmigrantes latinos para sobrevivir en los Estados Unidos. Las lenguas nativas se mantienen vivas para las futuras generaciones protegiéndolos de los forasteros.

Las mujeres ILI se convierten en transmisores transnacionales de conocimientos necesarios para acceder a sus regiones de origen sin correr el riesgo de físicamente cruzar las fronteras. Los participantes en este estudio mantienen fuertes vínculos con sus comunidades de origen. Basado en los resultados en este estudio, con el fin de entender plenamente la transnacionalidad y sus efectos en una familia, uno debe ver el rol de las mujeres como transmisores transnacionales al conservar y mantener las culturas e idiomas ILI.

Desafortunadamente, han permanecido inadvertidos por los investigadores, educadores y otros grupos que podrían beneficiarse mediante la comprensión de sus experiencias únicas y potencialmente ayudarles a vivir vidas menos marginadas. Finalmente, este estudio pone en entredicho y saca a la luz el papel de las mujeres ILI en el desarrollo y crecimiento de sus comunidades en los Estados Unidos. Pero también destaca que continúan siendo blancos fáciles, ya que a menudo están en la primera línea de defensa - por ellas mismas y para sus familias. a chameleon is the antidote to living a life run by fear.

\section{Conclusion}

Being camaleónas guerreras is a survival strategy that encompasses physical, social and cultural elements which are manifested as multilingual, multicultural disguises that enables them to move fluidly across multiple identities. Teaching how to use these tools is a way for ILI women to help their families survive physically and socially in a world where indigenous peoples are ostracized, abused and even killed. They make conscious, situational choices in terms of language and behavior with the goal of blending in. Many ILI women even use language as camouflage within mainstream Latino immigrants in order to survive in the United States. Native languages are kept alive for future generations by protecting them from outsiders.

ILI women become transnational transmitters of skills necessary to access their home regions without taking the risk of physically crossing borders. The participants in this study maintain strong ties to their communities of origin. Based on the findings in this study, in order to fully understand transnationality and its effects on a family, one must look at the role of women as transnational transmitters as they preserve and maintain ILI languages and cultures. Unfortunately, they have remained unnoticed by researchers, educators and other groups who could benefit by understanding their unique experiences and potentially help them live less marginalized lives. Finally, this study calls into question and brings to light the role of ILI women in the development and growth of their communities in the United States. But it also highlights that they continue to be easy targets, as they are often the first line of defense-for themselves and their families.

[ 42 ] MARGARITA MACHADO-CASAS

SIPS - PEDAGOGIA SOCIAL. REVISTA INTERUNIVERSITARIA [1139-1723 (2014) 23, 21-44] TERCERA ÉPOCA 


\section{Bibliografía / References}

Anderson, W. (1997). Familias purépechas en el sur de Illinois: La (re)construcción de la identidad étnica. Paper presented at the XIX Coloquio de Antropología e Historia Regionales, El Colegio de Michoacán, Ciudad de Zamora.

Anzaldua, G. (1987). Borderlands/la frontera: The new mestiza. San Francisco, CA: Aunt Lute Books.

Aranda, E. M. (2006). Emotional bridges to Puerto Rico: Migration, return migration, and the struggles of incorporation. New York, NY: Rowman \& Littlefield.

Basch, L., Schiller, N. and Szanton Blanc, C. (1994). Nations unbound: Transnational projects, postcolonial predicaments and deterritorialized nation-states. Amsterdam: Gordon \& Breach.

Clandinin, D. J., \& Connelly, F. M. (2000). Narrative inquiry: Experience and story in qualitative research. San Francisco, CA: Jossey-Bass.

Creswell J. (1998). Qualitative inquiry and research design: Choosing among five traditions. Thousand Oaks, CA: Sage Publications.

Delgado-Gaitan, C. (1990). Literacy for empowerment: The role of parents in children's education. Bristol: The Falmer Press.

Durand, J., \& Massey, D. S. (2004). What we learned from the Mexican migration project. In J. Durand, \& D. S. Massey (Eds.), Crossing the border: Research from the Mexican migration project (pp. 1-16). Berkeley, CA: University of California Press.

Flores, N., Hernández León, R., \& Massey, D. R. (2004). Social capital and emigration from rural and urban communities. In J. Durand, \& D. S. Massey (Eds.), Crossing the border: Research from the Mexican migration project (pp. 184-200). New York, NY: Russell Sage Foundation.

Fox, J. (2006). Reframing Mexican migration as a multi-ethnic process. Latino Studies, (4), 39-61.

Fox, J., \& Rivera-Salgado, G. (Eds.) (2004). Indigenous Mexican migrants in the United States. La Jolla, CA: University of California, San Diego, Center for Comparative Immigration Studies and Center for US-Mexican Studies.

Gibson, M., Gandara, P., \& Koyama, J. (2004). School connections: U.S. Mexican youth, peers, and school achievement. New York, NY: Teachers College Press.

Glick Schiller, N., Basch, L., \& Szanton-Blank, C. (1992). Transnationalism: A new analytic framework for understanding migration. In N. Glick Schiller, L. Basch, \& C. Szanton-Blank, (Eds.), Toward a transnational perspective on migration (pp. 124). New York, NY: New York Academy of Sciences.

González, N. (2001). I am my language: Discourses of women and children in the borderlands. Tucson, AZ: The University of Arizona Press.

Guerra, J. C. (1998). Close to home: Oral and literate practices in a transnational Mexicano community. New York, NY: Teachers College Press.

Machado-Casas, M. (2006). Narrating education of new Indigenous/Latino transnational communities in the South. Unpublished dissertation. Chapel Hill, NC: University of North Carolina at Chapel Hill.

Machado-Casas, M. (2009a). La supervivencia transnacional de inmigrantes indígenas en Estados Unidos por medio de la tecnología informártica. DIDAC, 54, 13-23.

Machado-Casas, M. (2009b). The politics of organic phylogeny: The art of parenting and surviving as transnational multilingual Latino Indigenous immigrants in the U.S. High School Journal, 92(4), 82-99.

Machado-Casas, M. (2010). The new global transnational citizen: The role of multilingualism in the lives of Latino/s indigenous immigrants in the U.S. CIMEXUS: Revista de Investigaciones México Estados Unidos, 2(7), 99-123.

Machado-Casas, M. (2010). Puppet Pedagogies: Indigenous Latino Immigrant's and Public School in the US. Unpublished manuscript.

Massey, D. S. (1999). International migration at the dawn of the twenty-first century: The role of the state. Population and Development Review, 25(2), 303-323.

Merriam, S. B. (1998). Qualitative research and case study: Applications in education. San Francisco, CA: Jossey-Bass Publishers.

Nieto, S. (2004). Affirming diversity: The sociopolitical context of multicultural education (6 ${ }^{\text {th }}$ Ed.). New York: Pearson Education.

Ong, A., \& Nonini, D. (Eds.) (1997). Ungrounded empires: The cultural politics of modern Chinese transnationalism. New York, NY: Routledge Publishers.

Passel, J. S. \& Suro, R. (2005). Rise, Peak, and Decline: Trends in U.S. Immigration 1992-2004. September. Washington DC: Pew Hispanic Center.

Portes, A., \& Rumbaut, R. G. (2001). Legacies: The store of the immigrant second generation. New York, NY: Russell Sage Foundation.

Rivera-Salgado, G. (1999). Migration and political activism: Mexican transnational Indigenous communities in a comparative perspective. Ph.D. Dissertation. Santa Cruz, CA: University of California, Santa Cruz.

Sánchez, P. \& Machado-Casas, M. (2009). Introduction: At the intersection of transnationalism, Latina/o Immigrants, and education. High School Journal, 92(4), 3-15. 
Schiller, N., Basch, L., \& Szanton-Blanc, C. (1992). Transnationalism: A New Analytic Framework for Understanding Migration'. Toward a Transnational Perspective on Migration. N. Glick Schiller, Basch, L., \& Szanton-Blank, C. (eds). New York, New York Academy of Sciences: 1-24.

Stephen, L. (2007). Transborder lives: Indigenous Oaxacans in Mexico, California, and Oregon. Durham, NC: Duke University Press.

Trueba, E. (2004). The new Americans: Immigrants and transnationals at work. New York, NY: Rowman \& Littlefield Publishers Inc.

Urrieta, L., Jr. (2009). Fighting from within! Chicana and Chicano educators in U.S. schools. Tucson, AZ: University of Arizona Press

Valdés, G. (1996). Con respeto. Bridging the distance between culturally diverse families and schools. New York, NY: Teachers College Press.

Vasquez, O. A., Pease-Alvarez, P., \& Shannon, S. M. (1994). Pushing boundaries: Language and culture in a Mexicano community. New York, NY: Cambridge University Press.

Vertovec, S. (1999). Conceiving and researching transnationalism. Ethnic and Racial Studies, 22(2).

Zabin, C., Kearney, M., Garcias, A., Runsten, D., \& Nagengast, C. (1993). Mixtec migrants in California agriculture: A new cycle of poverty. Davis, CA: California Institute for Rural Studies.

Zentella, A. C. (1997). Growing up bilingual: Puerto Rican children in New York. Malden, MA: Blackwell Publishers.

\section{CÓMO CITAR ESTE ARTÍCULO / HOW TO CITE THE ARTICLE}

Machado-Casas, M. (2014). Supervivencia y transcendencia de inmigrantes latinas indígenas transnacionales (ILIs) en los Estados Unidos. Pedagogía Social. Revista Interuniversitaria, 23 21-44. DOI: 10.7179/ PSRI_2014.23.02

Machado-Casas, M. (2014). Survival and transcendence of transnational indigenous latina immigrants (ilis) in the US . Pedagogia Social. Revista Interuniversitaria, 23 21-44. DOI: 10.7179/PSRI_2014.23.02

Fecha de recepción del artículo / received date: 29.VII.2013

Fecha de revisión del artículo: / reviewed date: 16.1X.2013

Fecha de aceptación final / accepted date: 26.IX.2013

\section{DIRECCIÓN DEL AUTOR/ AUTHOR' ADDRESSES}

Margarita Machado-Casas. The University of Texas at San Antonio. One UTSA Circle. San Antonio, TX 78249. 210-458-5571. US

Correo electrónico / e-mail: Margarita.machadocasas@utsa.edu

\section{PERFIL ACADÉMICO / ACADEMIC PROFILE}

Margarita Machado-Casas. La Dra. Margarita Machado-Casas es profesora de la Universidad de Texas en San Antonio en el Departamento de Educación y Desarrollo Humano. La Dra. Machado-Casas recibió su doctorado de la Universidad de Carolina del Norte en Chapel Hill y un post-doctorado del prestigioso instituto de investigaciones Frank Portter Graham en la UNC-Chapel Hill. Sus áreas de investigación incluyen migración, educación, pedagogía social, evaluación, y estudios en comunidades transnacionales. Es co-editora de revistas académicas prestigiosas, incluyendo el Journal de Latinos en Educación. Es la co-creadora de programas de maestría en Latino América y es la co-directora del National Education Latino Network (NELN) y del Latino Education Advocacy Days (LEAD) los cuales llegan a más de un millón de personas en el mundo.

[ 44 ] MARGARITA MACHADO-CASAS

SIPS - PEDAGOGIA SOCIAL. REVISTA INTERUNIVERSITARIA [1139-1723 (2014) 23, 21-44] TERCERA ÉPOCA 